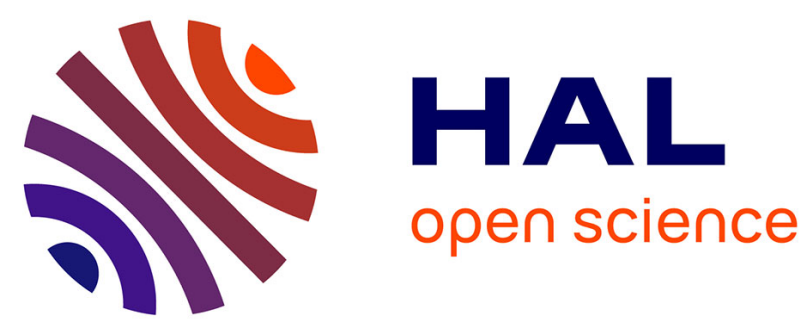

\title{
Trace organic contaminants within solid matrices along an anthropized watercourse: Organo-mineral controls on their spatial distribution
}

Maëlla Le Gaudu, Thomas Thiebault, Katell Quénéa, Fabrice Alliot, Elodie Guigon, Laurence Le Callonnec

\section{To cite this version:}

Maëlla Le Gaudu, Thomas Thiebault, Katell Quénéa, Fabrice Alliot, Elodie Guigon, et al.. Trace organic contaminants within solid matrices along an anthropized watercourse: Organomineral controls on their spatial distribution. Science of the Total Environment, 2022, pp.153601. 10.1016/j.scitotenv.2022.153601 . insu-03552025

\section{HAL Id: insu-03552025 \\ https://hal-insu.archives-ouvertes.fr/insu-03552025}

Submitted on 2 Feb 2022

HAL is a multi-disciplinary open access archive for the deposit and dissemination of scientific research documents, whether they are published or not. The documents may come from teaching and research institutions in France or abroad, or from public or private research centers.
L'archive ouverte pluridisciplinaire HAL, est destinée au dépôt et à la diffusion de documents scientifiques de niveau recherche, publiés ou non, émanant des établissements d'enseignement et de recherche français ou étrangers, des laboratoires publics ou privés. 


\title{
Trace organic contaminants within solid matrices along an anthropized
}

\section{watercourse: Organo-mineral controls on their spatial distribution}

Maëlla Le Gaudu ${ }^{\mathrm{a}}$, Thomas Thiebault $\mathrm{a}^{\mathrm{a}^{*}}$, Katell Quénéa ${ }^{\mathrm{a}}$, Fabrice Alliot ${ }^{\mathrm{a}}$, Elodie Guigon ${ }^{\mathrm{a}}$ and Laurence Le Callonnec ${ }^{\mathrm{b}}$

${ }^{a}$ METIS, Sorbonne Université, CNRS, EPHE, PSL University, UMR 7619, F-75005, Paris, France

b ISTeP, Sorbonne Université, CNRS, UMR 7193, F-75005, Paris, France

*To whom correspondence should be addressed. E-mail: thomas.thiebault@ephe.psl.eu Phone: +33

(0) 144275997

\begin{abstract}
Although numerous studies have determined significant contamination in terms of trace organic contaminant (TrOC) diversity and concentration, the occurrence of TrOCs within solid matrices as suspended solids and sediments flies under the radar. In this study, the occurrence of 35 TrOCs of various classes (i.e. pharmaceutical products and pesticides) was investigated in three compartments, namely dissolved phase, suspended particulate matter (SPM) and sediments, within an anthropized river in France. The sampling was performed to assess the spatial contamination dynamics and the impact of a major wastewater treatment plant (WWTP), under two contrasted hydrological conditions, i.e. base level and flood conditions. Solid samples were finely characterized (XRD, grainsize, TOC) in order to assess the impact of organic and mineral composition on the sorption extent of TrOCs. The study reveals that the clear spatial pattern of contamination in water samples, mostly generated by the effluent discharge of WWTPs, is less clear in solid matrices as the variability of the organo-mineral composition of such samples strongly impacts their favourability for sorption. Moreover, the flood event strongly impacted the sedimentary compartment, remobilizing fine and TrOC contaminated particles that were further found in suspended particulate matter. Lastly, the representativeness of contaminant
\end{abstract}


diversity and concentration within the solid matrices displayed more favourable insights for SPM.

\section{Keywords}

Pharmaceuticals; Pesticides; Sediments; Partition; Sorption

\section{Introduction}

In recent decades, trace organic contaminants (TrOCs) have been detected in numerous aquatic environments (Birch et al., 2015; Gogoi et al., 2018; Golovko et al., 2020). Many xenobiotic contaminants can be considered as TrOCs, among which pharmaceutical products and pesticides are particularly monitored, as they are considered as contaminants of emerging concern (Daughton, 2004). Several TrOCs, such as pharmaceutical products, are excreted via urine and faeces and reach aquatic environments after their incomplete removal within wastewater treatment plants (WWTP, Tran et al., 2018). Other possible sources are overflow from the urban water network (Kay et al., 2017; Paijens et al., 2021) or the leaching of sewage sludge from fields (Verlicchi and Zambello, 2015).

For pesticides, the main sources are agricultural or individual use with the runoff, leaching of field soil and/or atmospheric deposits (Botta et al., 2009; Carter, 2000), although urban point sources may account for a significant proportion of the flow (Blanchoud et al., 2004). Due to their global use in large quantities, TrOCs are continuously discharged into environmental compartments and especially water bodies. They are mostly considered as pseudo-persistent (Warner et al., 2019), as this continuous environmental discharge maintains the contamination despite significant mitigation through various processes such as photolysis, biodegradation and/or sorption (Yamamoto et al., 2009; Zhou and Broodbank, 2014). TrOCs may have some effects on aquatic organisms, for example the feminization of fishes (Brodin et 
al., 2013), gill deformity (Golovko et al., 2020) or even death in the event of very high concentrations (Li and Lin, 2015; Nunes et al., 2005). TrOCs may also have effects on human health, since contaminated surface waters or ground waters are used for drinking purposes and water treatment quality can be highly variable (Bexfield et al., 2019; Bruce et al., 2010). TrOCs can be carcinogenic, reprotoxic and may impact humans (Farré et al., 2008; Gwenzi and Chaukura, 2018). Because of these effects, these contaminants have become an important issue in aquatic pollution and it is therefore important to improve our knowledge about their fate.

TrOCs, which are rather hydrophilic, are mostly studied in the dissolved phase, even if their occurrences in solid matrices as sediments (Kerrigan et al., 2018; Thiebault et al., 2021a) and suspended particulate matter (SPM) are increasingly investigated (Ledieu et al., 2021; Niu et al., 2021). The distribution of contaminants between solid and dissolved phases differs according to the properties of both the solid phase and the TrOC (Kodešová et al., 2015; Nunes et al., 2019). The physico-chemical properties of the TrOC, such as the charge, $\mathrm{K}_{\mathrm{ow}}$ and $\mathrm{K}_{\mathrm{oc}}$, may have an impact (Vazquez-Roig et al., 2012; Zhou and Broodbank, 2014). The total organic carbon (TOC) content of the solid phase as well as the hydrodynamic phase may also impact the TrOC partition in sediments or SPM (Boulard et al., 2019; Quesada et al., 2014). In previous studies, it was assumed that rather hydrophobic TrOCs (e.g. amitryptiline, oxazepam) exhibited more pronounced sorption onto sediments presenting higher TOC values (Al-Khazrajy and Boxall, 2016; Stein et al., 2008; Svahn and Björklund, 2015). But beyond this significant impact of TOC content, the role of other factors is often overlooked. Yet, contrary to hydrophobic contaminants, for which it is considered that the role of mineral surfaces in their adsorption can be neglected (Mader et al., 1997), it is possible that for more hydrophilic compounds, such as those investigated below, mineral surfaces, which are also hydrophilic, may play a more important role (Schaffer et al., 2012; Scheytt et al., 2005), in particular clay minerals (Droge and Goss, 2013a; Thiebault, 2020). Due to their cation exchange capacity (which is the same 
as that of organic matter, Droge and Goss, 2013b) and high specific surface area, clay minerals are considered as favourable for the sorption of TrOCs, and especially cationic ones (Dordio et al., 2017; Thiebault et al., 2021b). Therefore, the objective of this paper is to try to go beyond TOC alone to understand the factors controlling the spatial dynamic of TrOC sedimentary occurrences within an anthropized catchment. To achieve this objective, TrOC levels in different finely characterised matrices were analysed spatially and temporally in an anthropized river.

\section{Material and Methods}

\subsection{Site settings and sampling}

The study area is situated in the Orge River catchment $\left(956 \mathrm{~km}^{2}\right)$ in the North of France (Figure 1). The catchment is situated $30 \mathrm{~km}$ south of Paris and the Orge River is a tributary of the Seine River. The Orge basin presents a population density of $3000 \mathrm{inh} . \mathrm{km}^{-2}$ in the downstream area. This catchment shows an urbanization gradient from prevalently agricultural and partially forested areas upstream to more densely urbanized areas downstream and nearer the junction with the Seine River, as exhibited in Figure 1. A major WWTP with a capacity of 66,667 PE (population-equivalent) is located in the centre of the study area and discharges $60 \%$ of its effluent into the Orge river and $40 \%$ into the Rémarde river (which is a tributary of the Orge river). Upstream, about 10 small WWTPs discharge their effluents into the Rémarde river with a cumulative PE of 8,000. The upstream Rémarde contamination by TrOCs, especially by antibiotics, was already characterized in previous studies (Dinh et al., 2017a, 2017b) 


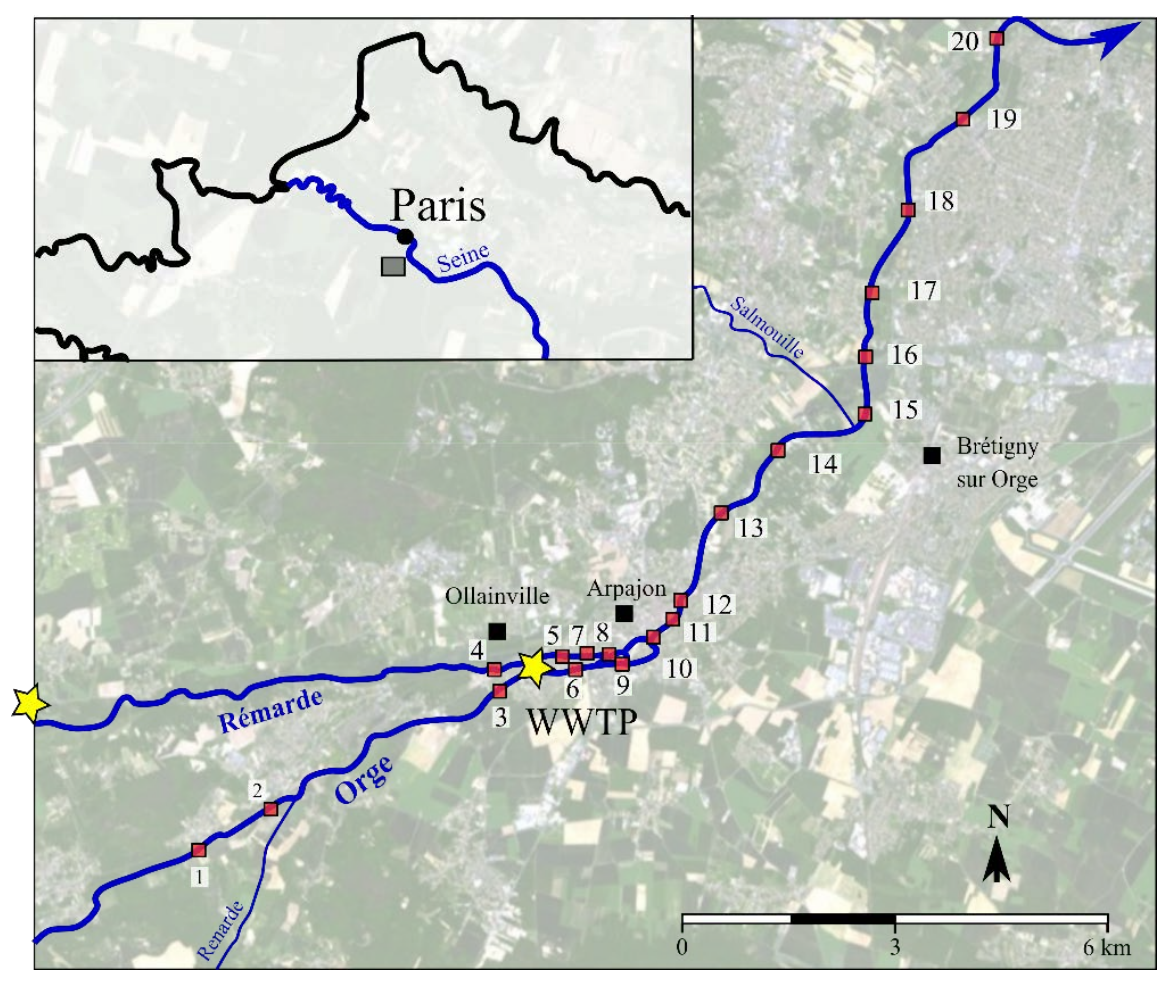

Figure 1. Aerial photograph (www.geoportail.gouv.fr) showing the sampling stations within the Orge catchment. Yellow stars indicate the significant WWTP effluent discharges, with a major WWTP in Ollainville and effluents from rural WWTPs in the Rémarde catchment

The major WWTP operates on the principle of activated sludge followed by ultrafiltration.

Two sampling campaigns were carried out, respectively in October 2020 (I) and in February 2021 (II) in the Orge and Rémarde rivers. 20 stations (i.e. 16 in the Orge river, 4 in the Rémarde river) were targeted during each campaign with sediment sampling in all stations, and water sampling (10 L) in only 10 stations per campaign. Some basic water parameters $(\mathrm{pH}$, Temperature and Conductivity) were systematically measured in the field, and Dissolved Organic Carbon (DOC) was also evaluated on $0.45 \mu \mathrm{m}$ filtered and $1 \mathrm{M} \mathrm{HNO}_{3}$ acidified samples using a DOC analyser (Shimadzu). These data are available in Table S1.

Sediments were sampled using an Eckman grab, and SPM were recovered after GF/F filtration of the $10 \mathrm{~L}$ water sample.

The main difference between the two campaigns is the hydrological conditions, with baseline water levels in October 2020 (mean flow value of $1.5 \mathrm{~m}^{3} \mathrm{~s}^{-1}$ ) and flood conditions in February 
2021 with a mean flow value of $4.5 \mathrm{~m}^{3} \mathrm{~s}^{-1}$ (and a maximum flow rate of $12.3 \mathrm{~m}^{3} \mathrm{~s}^{-1}$ few days earlier).

\subsection{Chemical reagents}

LC-MS grade acetonitrile (AcN) and methanol (MeOH) were purchased from VWR and ultrapure water $\left(\mathrm{H}_{2} \mathrm{O}\right)$ was prepared with a Pure Lab Chorus water purification system (Veolia Water). Formic acid (99\% purity) was purchased from Sigma-Aldrich. Isotopically labeled internal standards (ILIS) (Table S2) and reference standards (Table 1) were purchased from LGC Standards, assuming a purity $\geq 97 \%$. TrOCs were selected following the most frequently detected organic contaminants in European river waters (Loos et al., 2013).

Table 1: General properties of the targeted TrOCs, with Ab. the abbreviation, $\mathrm{M}_{\mathrm{w}}$ the molecular weight in $\mathrm{g} \mathrm{mol}^{-1}$, $\mathrm{Sol}_{\mathrm{w}}$ the water solubility at $25^{\circ} \mathrm{C}$ and $\mathrm{pH}=7 \mathrm{in} \mathrm{mg} \mathrm{L}^{-1}$, Charge the charge state at $\mathrm{pH}=7$ and * indicates by-products. ${ }^{\ddagger}$ Data extracted from Chemspider Database

\begin{tabular}{|c|c|c|c|c|c|c|c|c|c|c|}
\hline Type & Name & Ab. & Formula & CAS-Number & $\mathrm{M}_{\mathrm{w}}^{\ddagger}$ & $\mathrm{pK}_{\mathrm{a}}^{\ddagger}$ & $\log \mathrm{K}_{\mathrm{ow}}{ }^{\ddagger}$ & $\log K_{o c}^{\ddagger}$ & Sol $_{w}^{\ddagger}$ & Charge \\
\hline \multicolumn{11}{|l|}{ Pharmaceuticals } \\
\hline \multirow[t]{5}{*}{ Antibiotics } & Flumequine & FLQ & $\mathrm{C}_{14} \mathrm{H}_{12} \mathrm{FNO}_{3}$ & $42,835-25-6$ & 261.25 & 6.0 & 2.60 & 1.85 & 308 & - \\
\hline & Ofloxacin & OFL & $\mathrm{C}_{18} \mathrm{H}_{20} \mathrm{FN}_{3} \mathrm{O}_{4}$ & $82,419-36-1$ & 361.37 & $5.5-6.2$ & -2.00 & 1.65 & 4000 & - \\
\hline & Oxolinic Acid & $\mathrm{OXO}$ & $\mathrm{C}_{13} \mathrm{H}_{11} \mathrm{NO}_{5}$ & $14,698-29-4$ & 261.23 & 5.6 & 1.70 & 1.00 & 3.2 & - \\
\hline & Sulfamethoxazole & SMX & $\mathrm{C}_{10} \mathrm{H}_{11} \mathrm{~N}_{3} \mathrm{O}_{3} \mathrm{~S}$ & $723-46-6$ & 253.28 & $2.0-6.2$ & 0.89 & 3.19 & 610 & - \\
\hline & Trimethoprim & TMP & $\mathrm{C}_{14} \mathrm{H}_{18} \mathrm{~N}_{4} \mathrm{O}_{3}$ & $738-70-5$ & 290.32 & 7.2 & 0.91 & 2.96 & 400 & $0 /+$ \\
\hline \multirow[t]{3}{*}{ Analgesics } & Acetaminophen & ACM & $\mathrm{C}_{8} \mathrm{H}_{9} \mathrm{NO}_{2}$ & $103-90-2$ & 151.16 & 9.6 & 0.46 & 1.79 & 14,000 & 0 \\
\hline & Codeine & COD & $\mathrm{C}_{18} \mathrm{H}_{21} \mathrm{NO}_{3}$ & $76-57-3$ & 299.36 & 8.2 & 1.28 & 3.12 & 577 & + \\
\hline & Tramadol & TRA & $\mathrm{C}_{16} \mathrm{H}_{25} \mathrm{NO}_{2}$ & $27,203-92-5$ & 263.37 & 9.4 & 3.01 & 2.91 & 1,151 & + \\
\hline Anticonvulsants & Carbamazepine & $\mathrm{CBZ}$ & $\mathrm{C}_{15} \mathrm{H}_{12} \mathrm{~N}_{2} \mathrm{O}$ & $298-46-4$ & 236.27 & 13.9 & 2.45 & 3.56 & 18 & 0 \\
\hline \multirow[t]{3}{*}{$\beta$-blockers } & Atenolol & ATE & $\mathrm{C}_{14} \mathrm{H}_{22} \mathrm{~N}_{2} \mathrm{O}_{3}$ & $29,122-68-7$ & 266.34 & 9.6 & 0.16 & 2.17 & 13,300 & + \\
\hline & Metoprolol & MET & $\mathrm{C}_{15} \mathrm{H}_{25} \mathrm{NO}_{3}$ & $51,384-51-1$ & 267.36 & 9.7 & 1.79 & 1.79 & 4,700 & + \\
\hline & Propranolol & PRP & $\mathrm{C}_{16} \mathrm{H}_{21} \mathrm{NO}_{2}$ & 525-66-6 & 259.34 & 9.7 & 2.60 & 3.09 & 61.7 & + \\
\hline \multirow{3}{*}{$\begin{array}{l}\text { Non-Steroidal } \\
\text { Anti-Inflammatory Drugs }\end{array}$} & Diclofenac & DCF & $\mathrm{C}_{14} \mathrm{H}_{11} \mathrm{Cl}_{2} \mathrm{NO}_{2}$ & $15,307-79-6$ & 296.15 & 4.2 & 4.02 & 2.92 & 2.37 & - \\
\hline & Ibuprofen & IBU & $\mathrm{C}_{13} \mathrm{H}_{18} \mathrm{O}_{2}$ & $15,687-27-1$ & 206.28 & 4.9 & 3.79 & 2.60 & 21 & - \\
\hline & Ketoprofen & KET & $\mathrm{C}_{16} \mathrm{H}_{14} \mathrm{O}_{3}$ & $22,071-15-4$ & 254.28 & 4.5 & 3.00 & 2.46 & 51 & - \\
\hline \multirow[t]{2}{*}{ Psychotropic drugs } & Oxazepam & OXA & $\mathrm{C}_{15} \mathrm{H}_{11} \mathrm{ClN}_{2} \mathrm{O}_{2}$ & $604-75-1$ & 286.71 & $1.7-11.6$ & 3.34 & 3.08 & 150 & 0 \\
\hline & Venlafaxine & VEN & $\mathrm{C}_{17} \mathrm{H}_{27} \mathrm{NO}_{2}$ & $93,413-69-5$ & 277.40 & 8.9 & 3.28 & 3.17 & 267 & + \\
\hline \multicolumn{11}{|l|}{ Pesticides } \\
\hline Fungicide & Tebuconazole & TEB & $\mathrm{C}_{16} \mathrm{H}_{22} \mathrm{ClN}_{3} \mathrm{O}$ & $107,534-96-3$ & 307.82 & 5.0 & 3.89 & 4.32 & 36 & 0 \\
\hline \multirow[t]{15}{*}{ Herbicides } & 3,4 Dichloroaniline* & DCA & $\mathrm{C}_{6} \mathrm{H}_{5} \mathrm{Cl}_{2} \mathrm{~N}$ & $95-76-1$ & 162.02 & 3.0 & 2.37 & 2.08 & 92 & 0 \\
\hline & Atrazine & ATZ & $\mathrm{C}_{8} \mathrm{H}_{14} \mathrm{ClN}_{5}$ & $1912-24-9$ & 215.68 & 1.7 & 2.82 & 2.36 & 33 & 0 \\
\hline & Desethylatrazine* & DEA & $\mathrm{C}_{6} \mathrm{H}_{10} \mathrm{ClN}_{5}$ & 6190-65-4 & 187.63 & 1.4 & 1.51 & 1.94 & 3200 & 0 \\
\hline & Deisopropylatrazine* & DIA & $\mathrm{C}_{5} \mathrm{H}_{8} \mathrm{ClN}_{5}$ & $1007-28-9$ & 173.60 & 1.5 & 1.15 & 1.75 & 670 & 0 \\
\hline & Hydroxyatrazine* & HTZ & $\mathrm{C}_{8} \mathrm{H}_{15} \mathrm{~N}_{5} \mathrm{O}$ & $2163-68-0$ & 197.24 & 4.6 & 2.09 & 2.25 & 5.9 & 0 \\
\hline & Chlortoluron & CHT & $\mathrm{C}_{10} \mathrm{H}_{13} \mathrm{ClN}_{2} \mathrm{O}$ & $15,545-48-9$ & 212.67 & - & 2.58 & 2.13 & 70 & 0 \\
\hline & Diflufenican & DFF & $\mathrm{C}_{19} \mathrm{H}_{11} \mathrm{~F}_{5} \mathrm{~N}_{2} \mathrm{O}_{2}$ & $83,164-33-4$ & 394.30 & - & 4.90 & 5.04 & 0.05 & 0 \\
\hline & Isoproturon & ISO & $\mathrm{C}_{12} \mathrm{H}_{18} \mathrm{~N}_{2} \mathrm{O}$ & $34,123-59-6$ & 206.28 & 0.1 & 2.84 & 2.40 & 70 & 0 \\
\hline & Metolachlor & MTC & $\mathrm{C}_{15} \mathrm{H}_{22} \mathrm{ClNO}_{2}$ & $51,218-45-2$ & 283.79 & - & 3.24 & 2.47 & 530 & 0 \\
\hline & Nicosulfuron & NIS & $\mathrm{C}_{15} \mathrm{H}_{18} \mathrm{~N}_{6} \mathrm{O}_{6} \mathrm{~S}$ & $111,991-09-4$ & 410.41 & $4.8-7.6$ & 0.60 & 1.33 & 7500 & - \\
\hline & Oxadiazon & OXD & $\mathrm{C}_{15} \mathrm{H}_{18} \mathrm{Cl}_{2} \mathrm{~N}_{2} \mathrm{O}_{3}$ & $19,666-30-9$ & 345.22 & - & 5.33 & 3.54 & 0.7 & 0 \\
\hline & Prosulfuron & PRS & $\mathrm{C}_{15} \mathrm{H}_{16} \mathrm{~F}_{3} \mathrm{~N}_{5} \mathrm{O}_{4} \mathrm{~S}$ & $94,125-34-5$ & 419.38 & 3.8 & 1.50 & 1.20 & 4000 & - \\
\hline & Pendimethalin & PEN & $\mathrm{C}_{13} \mathrm{H}_{19} \mathrm{~N}_{3} \mathrm{O}_{4}$ & $40,487-42-1$ & 281.31 & 11 & 3.95 & 4.05 & 2.6 & 0 \\
\hline & Simazine & SIM & $\mathrm{C}_{7} \mathrm{H}_{12} \mathrm{ClN}_{5}$ & $122-34-9$ & 201.66 & 1.6 & 2.40 & 2.17 & 6.2 & 0 \\
\hline & Terbuthylazine & TER & $\mathrm{C}_{9} \mathrm{H}_{16} \mathrm{ClN}_{5}$ & 5915-41-3 & 229.71 & 2.0 & 3.21 & 2.52 & 9 & 0 \\
\hline \multirow[t]{2}{*}{ Insecticides } & Imidacloprid & IMI & $\mathrm{C}_{9} \mathrm{H}_{10} \mathrm{ClN}_{5} \mathrm{O}_{2}$ & 138261-41-3 & 255.66 & 14 & -0.41 & 3.83 & 50,000 & 0 \\
\hline & Tebufenozide & TEF & $\mathrm{C}_{22} \mathrm{H}_{28} \mathrm{~N}_{2} \mathrm{O}_{2}$ & 112410-23-8 & 352.47 & 10.8 & 4.25 & 4.54 & 0.83 & 0 \\
\hline
\end{tabular}

\subsection{Enrichment and clean-up of samples}


Sampled sediments and suspended solids were frozen and then freeze-dried during 48h. For sediments, $1 \pm 0.1 \mathrm{~g}$ was subsampled and crushed in a mortar, while for suspended solids, loaded filters were directly used for extraction. Samples were then spiked with $50 \mathrm{ng}$ of each ILIS at $4^{\circ} \mathrm{C}$ overnight. Spiked samples were then extracted by pressurized liquid extraction, using ASE-350 (Thermo). The extraction mixture was $\mathrm{MeOH}$ and the operating temperature and pressure were $70^{\circ} \mathrm{C}$ and 1000 psi respectively. Extracts were then reduced to $1 \mathrm{~mL}$ using an EZ-2 evaporator (Biopharma Technologies), prior to refilling at $100 \mathrm{~mL}$ of milli-Q $\mathrm{H}_{2} \mathrm{O}$. For water samples, $200 \mathrm{~mL}$ were aliquoted and spiked with $50 \mathrm{ng}$ of each ILIS.

The next step was common to the three matrices investigated, the only difference being the sample volume for water samples (i.e. $200 \mathrm{~mL}$ ) contrary to the $100 \mathrm{~mL}$ of solid samples. Solid-phase extraction (SPE) was performed on CHROMABOND-HLB columns (6 mL x 150 mg x $30 \mu \mathrm{m}$, Macherey-Nagel). Cartridges were conditioned with $5 \mathrm{~mL}$ of $\mathrm{MeOH}$ followed by $5 \mathrm{~mL}$ of ultra-pure water. Then, the cartridges were filled with the sample (100 or $200 \mathrm{~mL}$ ) prior to flushing with $2 \times 5 \mathrm{~mL}$ of ultra-pure water before drying for 30 minutes under vacuum. Finally, elution of TrOCs was performed with 2 x $5 \mathrm{~mL}$ of MeOH before drying under nitrogen flow and filtration at $0.22 \mu \mathrm{m}$ (Nylon filter, VWR). Extracts were finally recovered in $\mathrm{MeOH}$ before injection. The analytical and quantification procedure is further detailed in the supplementary data (Tables S1-S2).

\subsection{Instrumentation}

TrOC separation was achieved at $40^{\circ} \mathrm{C}$ with a Nucleoshell Biphenyl chromatographic column (2 mm x 100 mm x 2.7 $\mu \mathrm{m}$; Macherey-Nagel ) with a fritted disc $(0.2 \mu \mathrm{m})$ used as pre-column, using a 1200 SL HPLC system (Agilent). The injection volume was $5 \mu \mathrm{L}$ and the flow rate 0.65 mL.min ${ }^{-1}$. Two solvents were used as mobile phase, AcN (solvent A) and Milli-Q water (solvent B), both acidified with $0.1 \%$ of formic acid. The elution gradient was a transition from $98 \%$ to $0 \%$ of B in 9.5 min followed by 2 min of $100 \%$ of A and then a return to the initial conditions 
(98\% of B) during 2 min for a total analysis time of 15 min. The chromatography system was coupled to a 6410B triple quadrupole mass spectrometer (Agilent) equipped with a heated electrospray ionization (H-ESI) interface operating in positive mode $\left(\mathrm{T}^{\circ}: 350^{\circ} \mathrm{C}\right.$; Gas flow: 3 L.min ${ }^{-1}$; Nebulizer: 15 psi). The dynamic multiple reaction monitoring (dMRM) transitions and further details on the detection and quantification procedures are given in the supplementary data (Tables S2-S3).

\subsection{Validation}

The limits of quantification (LOQ) and limits of detection (LOD) of the method were calculated using the signal-to-noise (S/N) ratios (Table S4). LOD and LOQ were determined by extracting spiked (100 ng g $\left.{ }^{-1}\right)$ matrix-matched $(n=5)$ sediment samples. Then, LOD and LOQ were respectively calculated based on a ratio between spiked amount and $\mathrm{S} / \mathrm{N}$ ratios multiplied by 3 and 10 for LOD and LOQ respectively. The recovery ratios were also evaluated in these experiments (spiking concentration $=100 \mathrm{ng} \mathrm{g}^{-1}, \mathrm{n}=5$ ), using the same extraction and quantification protocol as for the samples. Finally, during each analytical run, blanks and quantification controls were regularly used in order to crosscheck the quantification quality.

\subsection{Geochemical analyses}

The particle size of solid samples (i.e. sediments and SPM) was determined by an enhanced laser diffraction particle size analyzer (Beckman Coulter, LS 13320 XR). The granulometer operates with sample cells designed for particles suspended in liquids (Universal Liquid Module). The total organic carbon (TOC) content of sediment and SPM samples was determined by elementary analysis after decarbonation of the bulk sediment with $\mathrm{HCl}(3 \mathrm{M})$. X-ray powder diffraction (XRD) patterns of the different samples were recorded on a Bruker -

D2 Phaser with a Lynxeye detector diffractometer using $\mathrm{Cu} \mathrm{K} \alpha$ radiation $(\lambda=1.5418 \AA$; $30 \mathrm{kV}$, $10 \mathrm{~mA}$ ) and $\Theta-2 \Theta$ mounting (Bragg-Brentano geometry). Measurements were achieved for $2 \Theta$ 
angles values between 2 and $70^{\circ}$, step $0.02^{\circ} 2 \Theta$, on powdered samples (granulometry: $40 \mu \mathrm{m}$ ). Relative quantification of the mineralogical phases was performed using Rietveld refinements (from Malvern Panalytical's HighScore Plus software) and assuming an error margin of 5\%.

\section{Results}

\subsection{TrOC occurrences}

The occurrences of TrOCs in the three matrices investigated (i.e. water, SPM and sediments) are presented in Table 2. Among the 35 TrOCs screened, all were detected at least once in one matrix.

In water, three molecules were not quantified: FLQ, PRS and TEF (Table S5). The quantification frequencies (QF) of the other TrOCs ranged from 10\% (for DCA and OXD) to higher than $80 \%$, for almost all the molecules. The maximum pesticide concentrations were tens of ng $\mathrm{L}^{-1}$, whereas for pharmaceuticals, hundreds of ng $\mathrm{L}^{-1}$ were reached by $5 \mathrm{TrOCs}$, namely ACM, TRA, DCF, OXA and VEN.

In SPM, 6 TrOCs were not quantified (Table 2), and a limited amount of TrOCs exhibited very significant quantification frequencies with 9 molecules displaying QF values higher than 80\%, including 7 pesticides. The concentrations ranged from around $1 \mathrm{ng} \mathrm{g}^{-1}$ to several tens of $\mathrm{ng} \mathrm{g}^{-}$ ${ }^{1}$ with an equivalent order of magnitude between pharmaceuticals and pesticides.

Finally, in sediments, one TrOC (i.e. DFF) was systematically quantified and on the other hand, 4 molecules (i.e. SMX, NIS, SIM and IMI) were not (Table S7). The median concentrations were around a few ng $\mathrm{g}^{-1}$ and the quantification frequencies were very variable. The maximum concentrations of 9 molecules exceeded tens of ng g-1 among which 8 pharmaceuticals.

Table 2: Minimum (min), median (med) and maximum (max) concentrations, in ng $\mathrm{L}^{-1}$ for Water samples and $\mathrm{ng} \mathrm{g}^{-1}$ for Suspended Particulate Matter (SPM) and Sediments, of TrOCs for the whole collected dataset with $\mathrm{n}_{\mathrm{Q}}$ the quantification number, n.d. for not detected molecule.

\begin{tabular}{llrrrrrrrrrrrr}
\hline & & \multicolumn{4}{c}{ Water $(\mathrm{n}=20)$} & \multicolumn{4}{c}{ SPM $(\mathrm{n}=20)$} & \multicolumn{4}{c}{ Sediments $(\mathrm{n}=40)$} \\
& & $\min$ & $\operatorname{med}$ & $\max$ & \multicolumn{1}{c}{ nQ } & $\min$ & $\operatorname{med}$ & $\max$ & $\mathrm{nQ}$ & $\min$ & $\operatorname{med}$ & $\max$ & $\mathrm{nQ}$ \\
\hline Pharmaceuticals & & & & & & & & & & & & \\
\hline Antibiotics & FLQ & n.d. & n.d. & n.d. & $0 / 20$ & n.d. & n.d. & n.d. & $0 / 20$ & 2.8 & 3.5 & 38.6 & $5 / 40$ \\
& OFL & 2.1 & 9.7 & 25.1 & $19 / 20$ & n.d. & n.d. & n.d. & $0 / 20$ & 0.6 & 1.2 & 32.7 & $17 / 40$ \\
& OXO & 1.0 & 2.9 & 5.3 & $20 / 20$ & 1.9 & 1.9 & 1.9 & $1 / 20$ & 1.9 & 4.4 & 6.3 & $6 / 40$ \\
& SMX & 1.4 & 28.0 & 63.2 & $19 / 20$ & 1.2 & 1.5 & 4.0 & $5 / 20$ & n.d. & n.d. & n.d. & $0 / 40$
\end{tabular}




\begin{tabular}{|c|c|c|c|c|c|c|c|c|c|c|c|c|c|}
\hline & TMP & 2.3 & 5.4 & 15.7 & $18 / 20$ & 0.3 & 1.8 & 2.9 & $16 / 20$ & 1.1 & 4.6 & 159.7 & $17 / 40$ \\
\hline \multirow[t]{3}{*}{ Analgesics } & ACM & 17.0 & 69.3 & 1171.5 & $20 / 20$ & 1.2 & 7.7 & 83.3 & $15 / 20$ & 0.6 & 1.0 & 2.5 & $10 / 40$ \\
\hline & COD & 0.5 & 12.7 & 57.5 & $18 / 20$ & n.d. & n.d. & n.d. & $0 / 20$ & 0.7 & 1.6 & 5.5 & $6 / 40$ \\
\hline & TRA & 4.0 & 61.8 & 335.2 & $19 / 20$ & 2.7 & 14.0 & 95.0 & $20 / 20$ & 0.8 & 6.4 & 212.9 & $26 / 40$ \\
\hline Anti-epileptics & $\mathrm{CBZ}$ & 1.2 & 33.7 & 81.9 & $20 / 20$ & 2.0 & 3.2 & 16.7 & $12 / 20$ & 0.8 & 2.1 & 4.6 & $11 / 40$ \\
\hline \multirow{3}{*}{$\beta$-blockers } & ATE & 4.3 & 15.0 & 47.6 & $18 / 20$ & 0.7 & 0.9 & 5.8 & $4 / 20$ & 1.4 & 3.4 & 6.6 & $7 / 40$ \\
\hline & MET & 1.3 & 2.8 & 9.1 & $17 / 20$ & 0.9 & 0.9 & 0.9 & $3 / 20$ & 0.6 & 1.4 & 5.3 & $9 / 40$ \\
\hline & PRP & 1.4 & 15.0 & 57.0 & $20 / 20$ & 0.8 & 1.5 & 20.2 & $13 / 20$ & 0.4 & 4.6 & 43.7 & $30 / 40$ \\
\hline \multirow[t]{3}{*}{ NSAIDs } & DCF & 7.0 & 74.1 & 159.8 & $20 / 20$ & 2.6 & 4.6 & 10.0 & $8 / 20$ & 0.6 & 1.1 & 2.2 & $11 / 40$ \\
\hline & IBU & 9.8 & 14.3 & 29.9 & $6 / 20$ & 7.7 & 11.8 & 15.8 & $2 / 20$ & 1.9 & 2.8 & 11.5 & $10 / 40$ \\
\hline & KET & 3.5 & 6.9 & 60.1 & $19 / 20$ & 1.5 & 2.6 & 5.5 & $8 / 20$ & 5.1 & 8.3 & 67.1 & $3 / 40$ \\
\hline \multirow[t]{2}{*}{ Psychotropic drugs } & OXA & 6.4 & 36.9 & 112.5 & $16 / 20$ & 2.1 & 18.4 & 38.0 & $6 / 20$ & 1.8 & 5.5 & 11.6 & $8 / 40$ \\
\hline & VEN & 0.5 & 38.7 & 113.6 & $20 / 20$ & 5.3 & 7.6 & 27.4 & $12 / 20$ & 0.5 & 1.5 & 5.0 & $21 / 40$ \\
\hline \multicolumn{14}{|l|}{ Pesticides } \\
\hline Fungicides & TEB & 1.3 & 2.9 & 4.4 & $20 / 20$ & 0.9 & 2.5 & 8.2 & $19 / 20$ & 0.4 & 0.6 & 1.3 & $21 / 40$ \\
\hline \multirow[t]{15}{*}{ Herbicides } & DCA & 2.8 & 3.8 & 4.9 & $2 / 20$ & 1.2 & 3.4 & 4.3 & $4 / 20$ & 2.0 & 3.3 & 9.7 & $17 / 40$ \\
\hline & ATZ & 7.6 & 11.4 & 18.6 & $20 / 20$ & 0.2 & 0.6 & 2.6 & $15 / 20$ & 0.3 & 0.4 & 0.4 & $4 / 40$ \\
\hline & DEA & 19.3 & 29.0 & 38.4 & $20 / 20$ & 0.5 & 1.1 & 6.6 & $14 / 20$ & 0.3 & 0.5 & 0.7 & $4 / 40$ \\
\hline & DIA & 4.3 & 6.5 & 12.4 & $20 / 20$ & n.d. & n.d. & n.d. & $0 / 20$ & 0.8 & 0.8 & 0.8 & $1 / 40$ \\
\hline & HTZ & 2.0 & 2.9 & 4.5 & $18 / 20$ & 0.3 & 1.0 & 3.6 & $19 / 20$ & 0.6 & 1.3 & 5.8 & $9 / 40$ \\
\hline & CHT & 1.9 & 18.3 & 29.0 & $20 / 20$ & 0.9 & 2.7 & 29.3 & $17 / 20$ & 0.5 & 1.3 & 4.5 & $24 / 40$ \\
\hline & DFF & 5.1 & 8.2 & 13.8 & $20 / 20$ & 2.7 & 20.1 & 41.1 & $20 / 20$ & 0.5 & 3.1 & 23.9 & $40 / 40$ \\
\hline & ISO & 0.9 & 1.4 & 3.1 & $7 / 20$ & 0.5 & 0.8 & 12.0 & $6 / 20$ & 0.3 & 0.4 & 0.5 & $2 / 40$ \\
\hline & MTC & 6.3 & 11.7 & 21.8 & $17 / 20$ & 0.2 & 0.4 & 1.0 & $16 / 20$ & 0.2 & 0.3 & 0.4 & $14 / 40$ \\
\hline & NIS & 1.8 & 9.3 & 20.3 & $7 / 20$ & n.d. & n.d. & n.d. & $0 / 20$ & n.d. & n.d. & n.d. & $0 / 40$ \\
\hline & OXD & 1.4 & 1.4 & 1.4 & $2 / 20$ & 0.8 & 3.0 & 31.3 & $19 / 20$ & 1.3 & 2.3 & 5.9 & $15 / 40$ \\
\hline & PEN & 2.7 & 6.2 & 8.5 & $20 / 20$ & 2.2 & 5.3 & 22.8 & $20 / 20$ & 1.0 & 2.3 & 9.6 & $33 / 40$ \\
\hline & PRS & n.d. & n.d. & n.d. & $0 / 20$ & 2.6 & 2.7 & 2.8 & $2 / 20$ & 0.2 & 0.3 & 1.1 & $8 / 40$ \\
\hline & SIM & 0.6 & 2.9 & 26.5 & $20 / 20$ & 1.1 & 1.7 & 3.2 & $5 / 20$ & n.d. & n.d. & n.d. & $0 / 40$ \\
\hline & TER & 0.9 & 1.1 & 5.4 & $11 / 20$ & n.d. & n.d. & n.d. & $0 / 20$ & 0.6 & 0.7 & 1.8 & $3 / 40$ \\
\hline \multirow[t]{2}{*}{ Insecticides } & IMI & 2.9 & 10.9 & 17.1 & $14 / 20$ & 3.7 & 6.2 & 11.6 & $4 / 20$ & n.d. & n.d. & n.d. & $0 / 40$ \\
\hline & TEF & n.d. & n.d. & n.d. & $0 / 20$ & 1.8 & 2.2 & 11.7 & $7 / 20$ & 1.3 & 1.8 & 2.9 & $11 / 40$ \\
\hline
\end{tabular}

\subsection{Geochemical analyses}

\subsubsection{Dissolved samples}

Beyond TrOC occurrence, some other parameters (Table S1) were measured on water samples in order to identify possible atypical samples. Whatever the station or the campaign, the $\mathrm{pH}$ value remained stable from station 5 onwards despite a slight decrease upstream from 8.2 to 8.0 during the first campaign, and from 8.3 to 8.2 during the second. Conversely, the conductivity increased steadily upstream to downstream, with higher values during the second campaign.

During the second campaign, DOC concentrations increased up to station 10 , then were stable downstream with values around 4.5 ppm, except for the stations located in the Rémarde river, which had higher concentrations (i.e. 5-5.5 ppm). During the first campaign, the same pattern occurred upstream, whereas downstream, much more variable values were measured (Table S1). 


\subsubsection{Solid samples}

The TOC of both SPM and sediment samples was analysed, whereas the grainsize and mineralogical content of sediments only were assessed due to limited SPM availability. The mean TOC value of SPM samples was $6.8 \%$ with a minimum value of $3.1 \%$ and a maximum value of $11.9 \%$, whereas the mean TOC value of sediment samples was $2.6 \%$ with a minimum value of 0.1 and a maximum value of $7.8 \%$. For SPM samples, the TOC values were higher during the second campaign with an average value of $8.2 \%$ compared to the first campaign with an average value of 5.3\%. The opposite pattern was observed for sediment samples, with a mean TOC value of $1.7 \%$ during the second campaign and of $3.5 \%$ during the first.

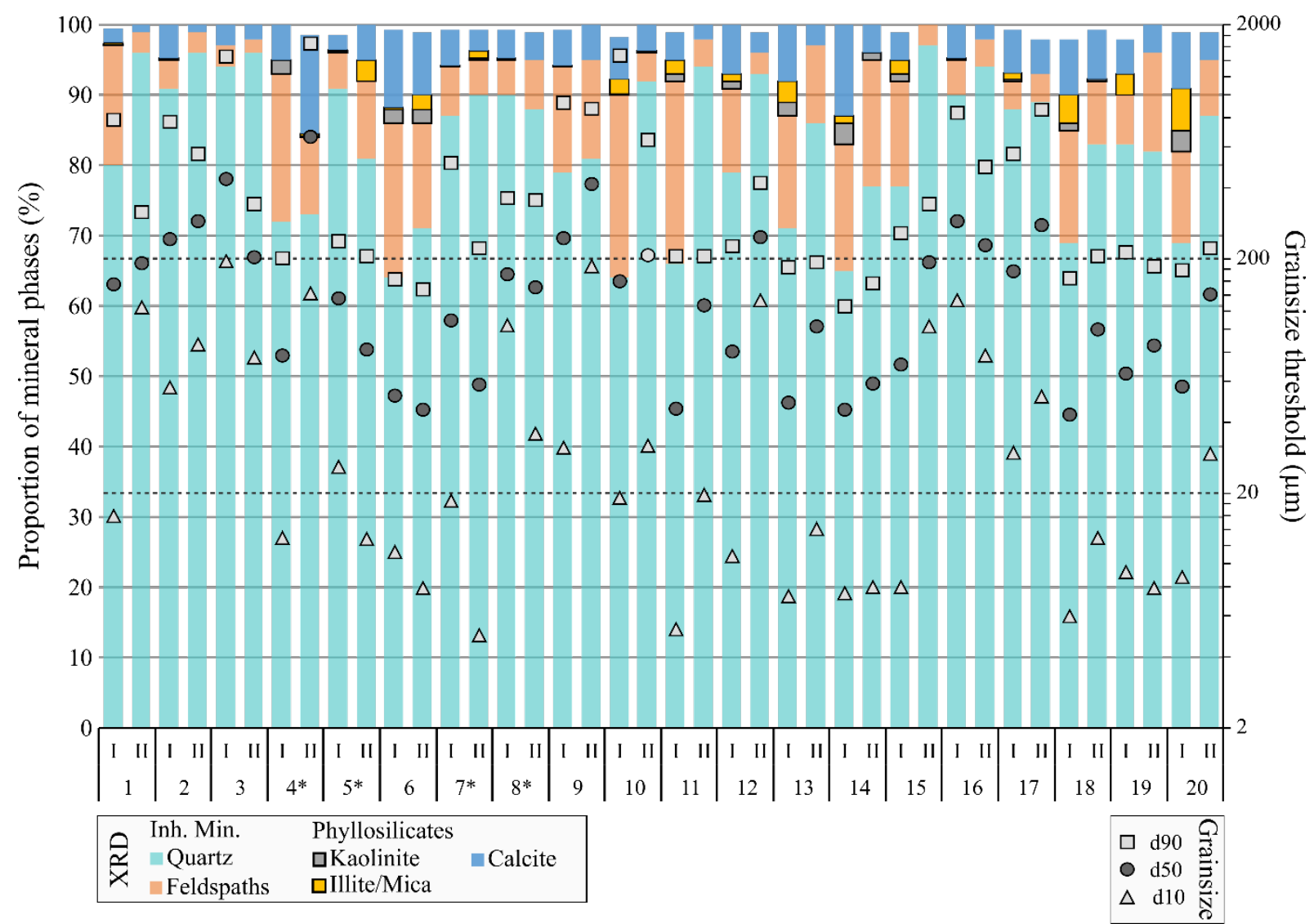

Figure 2: Mineralogical composition of each sediment sample, and grainsize threshold, with I for the October 2020 campaign, II for the February 2021 campaign and * for stations sampled in the Rémarde river.

Quantification of the mineralogical phases approximated through Rietveld refinement revealed 5 major phases. Quartz was the major mineral, accounting for at least $60 \%$ (Figure 2). The 
second most abundant phase was feldspaths with relative proportions between $2 \%$ and $26 \%$ and a mean value around $10 \%$. The third most abundant phase were calcium carbonates, which were dominated by calcite despite some occurrences of aragonite and dolomite. For clarity, these minerals were grouped under the label Calcite; they represented between 0.5 and $14 \%$ of the mineralogical composition of the samples, with a mean value of $5 \%$. The remaining phases were phyllosilicates which were separated into Kaolinite (for 1:1 clay minerals) and Illite/Mica (for 2:1 clay minerals). These minerals were not systematically present in the samples, and the maximum proportion of kaolinite was estimated at 3\%, and $6 \%$ for illite/mica. It is worth noting that the proportion of quartz systematically increased for the same station during the second campaign. The only exception was station 5. This systematic increase in quartz content was accompanied by an almost general decrease in other mineralogical phases, mainly phyllosilicates and feldspaths (Figure 2). Hereafter, quartz and feldspaths will be grouped as inherited minerals, kaolinite and illite/mica as clay minerals, and all the carbonates are considered as calcite for clarity.

The particle size thresholds d10, d50 (i.e. median) and d90 are presented in Figure 2. D50 values ranged from 43 to $656 \mu \mathrm{m}$ with a mean value of 163 . No clear spatial pattern related to these threshold values was found, highlighting the high variability of hydrodynamic conditions (i.e. accumulation or transport areas), however, what is worth pointing out between the two campaigns is the better particle size sorting during the second campaign, except for two stations, 4 and 16 . This better sorting is emphasized by the decrease in $d 90$, the increase in $\mathrm{d} 10$, or both (Figure 2).

\section{Discussion}

\subsection{Spatial distribution of TrOCs}


As often described in the literature, the main sources of pharmaceuticals are WWTP effluents.

This is confirmed by the aqueous concentrations of pharmaceuticals (Figure 3), as the highest concentrations for each campaign were measured at station 7 (campaign I) or station 6 (campaign II), just downstream the major WWTP discharge. Station 4, on the Rémarde river, was also significantly contaminated due to upstream effluent discharge. Station 3, in contrast, was almost free of pharmaceutical contamination, except for antibiotics and ACM. From station 9 onwards, the overall pharmaceutical concentrations decreased slightly (Figure 3).

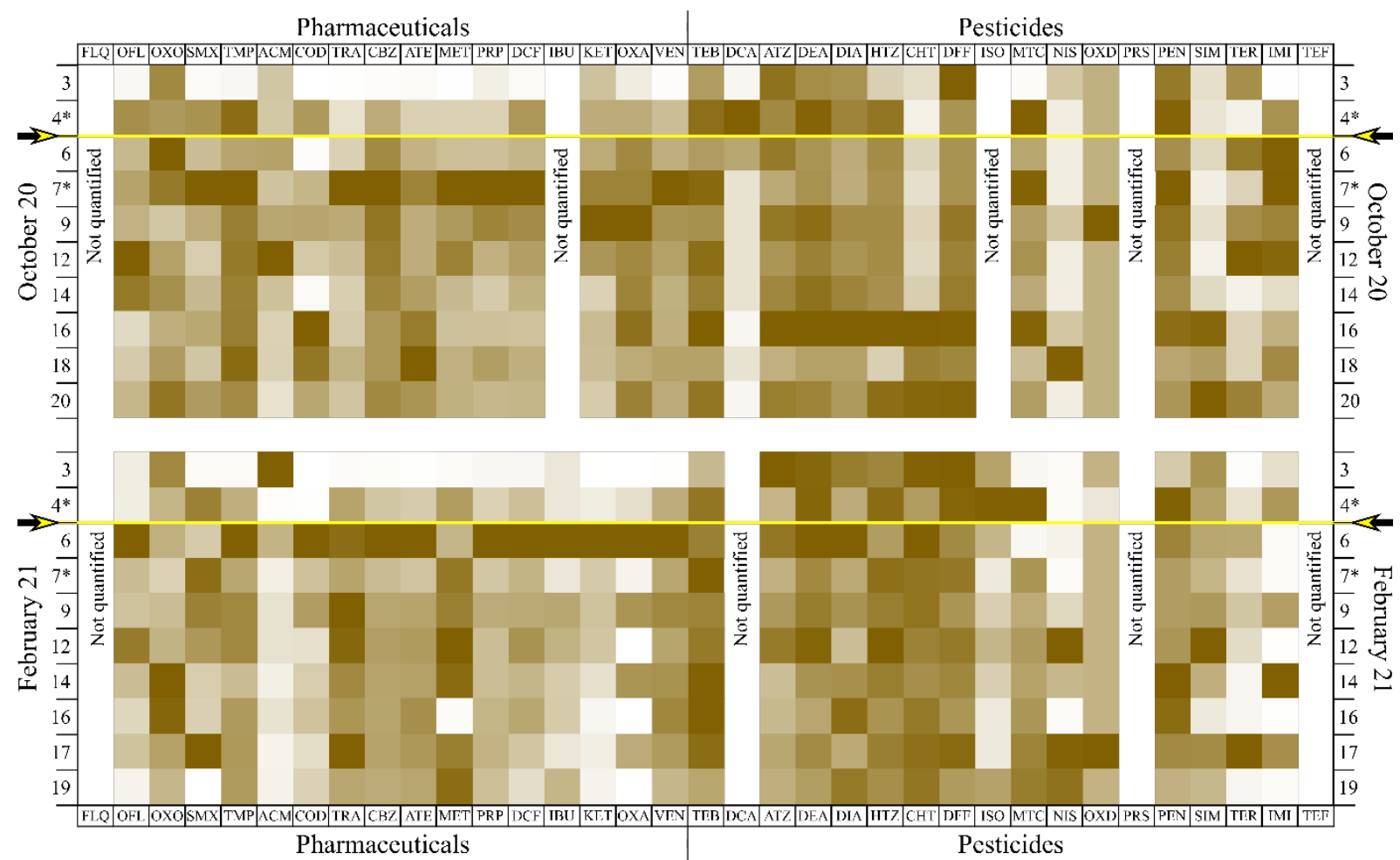

Figure 3: Spatial distribution of normalized (between 0 and 1) concentrations of TrOCs in aqueous samples for each sampling campaign. Full data are available in Table S5. Yellow arrows mark the WWTP effluent discharge locations.

The spatial distribution of pesticides in aqueous samples was less clear, which is unsurprising in view of their more diversified sources (i.e. diffuse and/or punctual). During campaign I, the most contaminated station was station 16, just downstream the confluence between the Orge and Salmouille rivers (Figure 1), whereas during the second campaign, pesticide concentrations 
were predominantly higher at the most upstream stations, despite some exceptions (e.g. IMI, TEF) illustrating the potential diversity of sources.

Turning to the spatial distribution in sedimentary concentrations (Figure 4), with a focus on pharmaceuticals for which the source is better identified, some common points with the aqueous distribution were observed. Among the 14 pharmaceuticals investigated, only 2 (i.e. OXO and ACM) were quantified (and only 1 during the second campaign) within the Orge catchment and before WWTP effluent discharge (stations 1-3). The diversity of quantified pharmaceuticals strongly increased in Rémarde samples, and after the discharge of WWTP effluents in the Orge river stations. Sediments may therefore be considered as a good compartment in order to assess contamination diversity. However, whereas the aqueous distribution exhibited an increasing concentration followed by a decreasing plateau, the sedimentary occurrences are far more irregular with variations over several orders of magnitude as for example for PRP or DFF (Figure 4). 


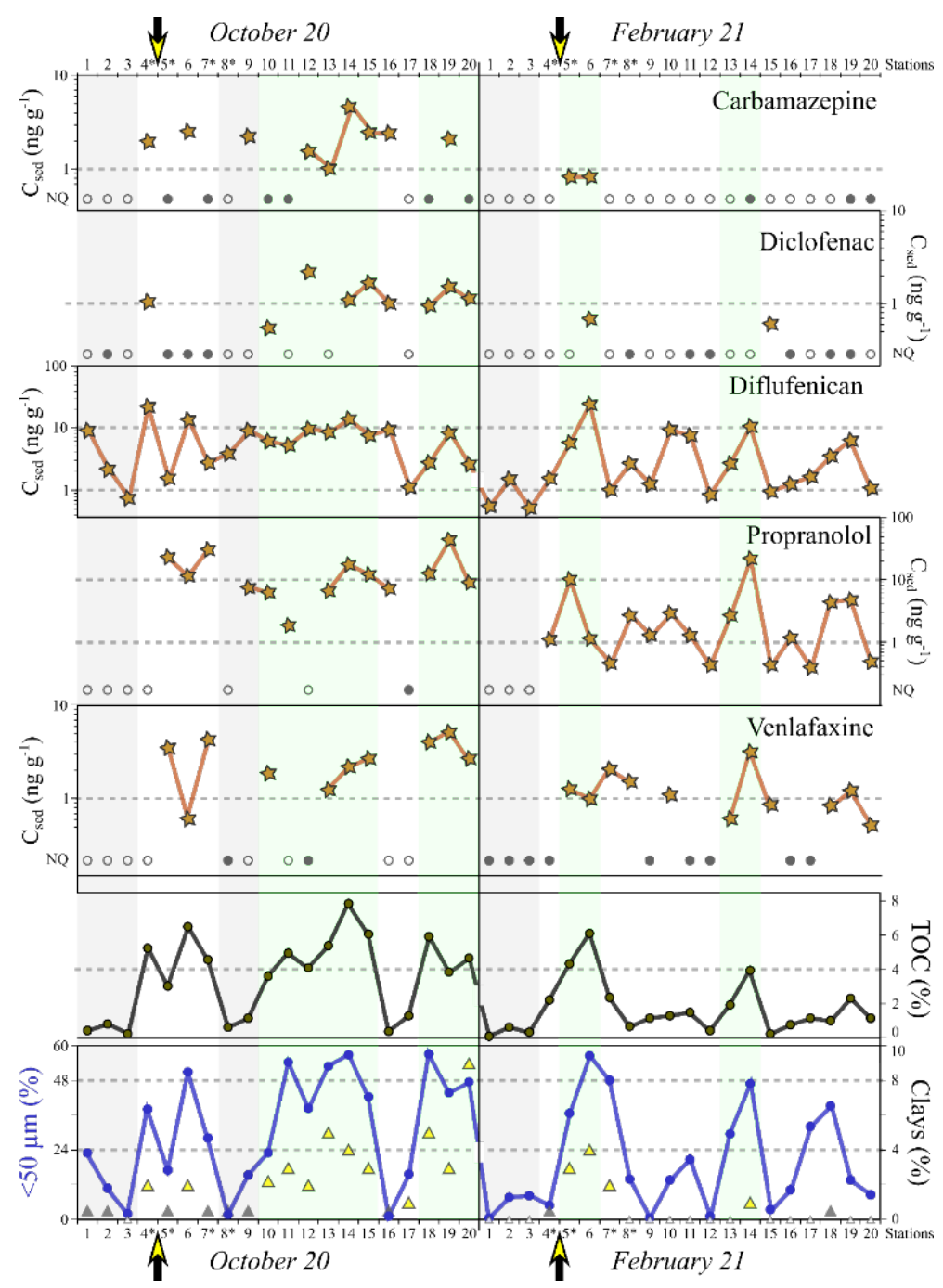

Figure 4: Spatial distribution of 5 TrOC sedimentary concentrations (Carbamazepine, Diclofenac, Diflufenican, Propranolol and Venlafaxine) in ng g-1 the TOC in \%, the mineralogical clay proportion (triangles) in $\%$ and grainsize $<50 \mu \mathrm{m}$ percentage (blue squares) in $\%$. White symbols mean $<\mathrm{LOD}$, grey symbols mean $<$ LOQ. Yellow arrows mark the WWTP effluent discharge locations and * for stations sampled in the Rémarde river.

This erratic spatial distribution can be explained by the variation in sediment composition itself.

From one station to another, the organo-mineral composition of sediments can change radically, from fine, organic and clay-rich composition, to coarse and mineral ones. It is obvious that these variations impact the sorption/partition extent of TrOCs onto sediments. For example, sample 14-II, which was organic-rich and fine, is heavily contaminated in comparison with 12-II which is coarse and mineral (Figure 4). It is therefore impossible to delineate a spatial distribution of TrOCs within riverine sediments without any normalization. 
Conversely, SPM samples were devoid of coarse particles (even if grainsize analyses were not performed on these samples) and more organic than sediment samples, and were therefore less heterogeneous along the water course. Some authors assume that the level of SPM contamination may be, in certain conditions, in equilibrium with that of the dissolved phase (Niu et al., 2021), which means that the solid/water partition coefficient (i.e. $K_{d}$ ) can be used in order to link aqueous and solid contamination. Judging from our results, such an equilibrium is not clearly evidenced (Figure S1). Even if the TrOC diversity (i.e. especially for pharmaceuticals), and the cumulative TrOC concentration increased after the discharge of WWTP effluents during the two campaigns, the trend is less clear than in dissolved samples as the upstream station (i.e. 3) is contaminated by pharmaceuticals, and the impact of WWTP effluent discharge on the cumulative concentration is not clearly evidenced, particularly during the second campaign (Figure S1).

\subsection{Impact of hydrological conditions on TrOC occurrences}

The two sampling periods covered very different hydrological conditions. Whereas the first campaign, in October 2020, was performed during baseline water level conditions, the second one was performed in a flooding context. By comparing the geochemical analyses of the sediment samples between the two campaigns, the mean TOC value was $1.7 \%$, the mean percentage of $<50 \mu \mathrm{m}$ grainsize was $20 \%$, and clay minerals were quantified in 6 samples during the second campaign, whereas these values were respectively 3.5\%, 31\% and 19 samples during the first campaign (Figure 4). The impact of the resuspension of fine materials between the two campaigns strongly controls the whole sorption capacity of sediments (Stachel et al., 2005), which is particularly supported by TOC and fine grainsize. The detection frequencies of TrOCs during the second campaign in sediments were therefore significantly lower than during the first campaign (Table S7), with median quantification frequencies of 30\% during the first campaign and $10 \%$ during the second. The impact of the flood event on SPM contamination 
was different, as SPM samples were more organic during the second campaign, highlighting either the resuspension of fine particles or erosion on the watershed (Lepage et al., 2020), and the hydrological continuity was also more pronounced, as underlined by the particularly stable DOC values during the second campaign, except for the Rémarde samples (Table S1). However, the TrOC occurrence was not significantly affected, as the same mean detection frequency of $44 \%$ was found for the two campaigns. During the flood event, both water flow and SPM flow increased, and in this study the SPM concentration was in the same order of magnitude. Considering that the solid/water partition is primarily controlled by the respective concentrations in the two matrices, and the fact that the geochemical properties of SPM did not dramatically change, it is logical to find similar concentrations during the two campaigns. It would obviously be very different if the reasoning were based on flow values (Poulier et al., 2019).

\subsection{What is the most representative solid matrix?}

As mentioned above, the monitoring of particulate concentrations of TrOCs is often neglected for some good reasons, such as their mostly hydrophilic character, and for some not so good reasons, such as the lack of representativeness of the sample (i.e. both spatial and temporal). However, these matrices are contaminated and it is important to assess their role in contaminant transfer within watersheds (Boulard et al., 2019), and what they have to tell us about the state of contamination of the environment. Our results show that the diversity of contaminants between the two matrices was almost the same (Figure 5), whereas the concentrations were systematically higher in SPM samples, even often within the same order of magnitude. It can be assumed that SPM are more favourable for the sorption of TrOC due to their higher TOC content and lower grainsize. This pattern is however not true for three molecules (TMP, PRP and ATE), all protonated at the occurring $\mathrm{pH}$ value. Therefore, $\log \mathrm{K}_{\mathrm{ow}}$ (or $\mathrm{K}_{\mathrm{oc}}$ ) was not the only parameter controlling the adsorption extent onto solid matrices (Hörsing et al., 2011; Li et 
al., 2020), as the mean TrOC concentrations remained almost within the same order of magnitude whatever the hydrophobicity. However, what is worth noting is the overall higher quantification frequencies for hydrophobic contaminants (Figure 5).

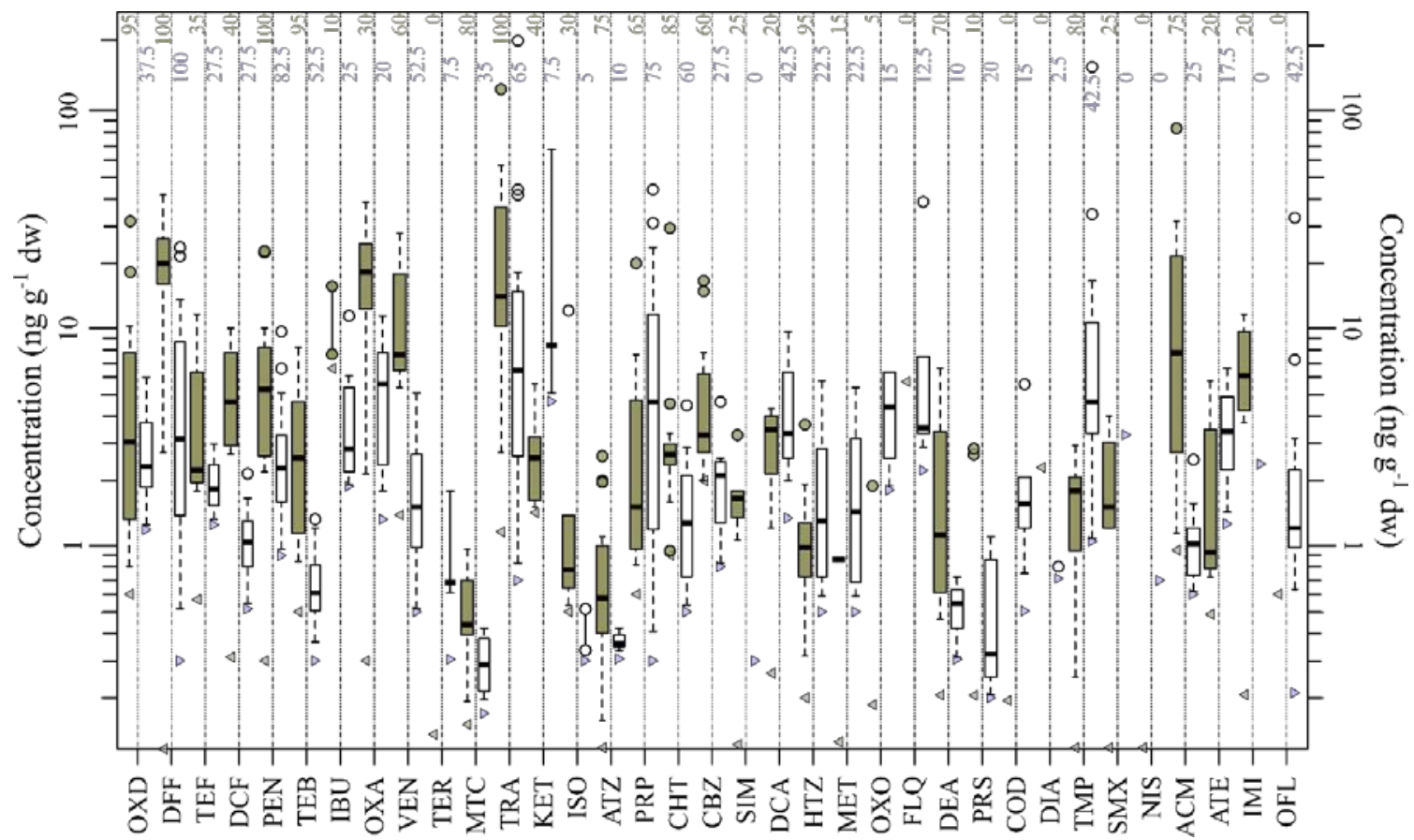

Figure 5: Boxplot of the TrOC concentrations in SPM (green box) and sediments (white box) sorted from the most hydrophobic (left) to the most hydrophilic (right) based on $\log \mathrm{K}_{\mathrm{ow}}$ values. Triangles mark the LOQ for each matrix. The line within the box marks the median, boundaries indicate the $25^{\text {th }}$ and $75^{\text {th }}$ percentiles, error bars indicate the maximum and minimal value in $\pm 1.5 \sigma$ variations and circles indicate individual values outside this range. Quantification frequencies are indicated in the upper part.

Therefore, SPM and sediment contamination appear to provide almost the same information about the contamination state of a water body, in terms of TrOC diversity. However, the more favourable organo-mineral properties of SPM imply higher levels of contamination, as previously observed for other contaminants (Dendievel et al., 2022), that may be easier to analyse and involve more consistent values for the evaluation of the chemical status.

\subsection{Relevant organo-mineral control of TrOC concentration}

In this study, sediment samples were characterized in detail. Specifically, beyond the TOC content and grainsize measurement, XRD analysis was also performed. This dataset also benefits from a statistical analysis in order to understand the potential correlation between the 
sediment properties and the TrOC occurrences (Figure 6). Indeed, organic carbon content is often considered as the main control of sedimentary occurrences of contaminants (Golovko et al., 2020), especially for hydrophobic contaminants (Castro and Vale, 1995). However, beyond organic carbon, some authors highlighted the impact of grainsize or even clay minerals (Kodešová et al., 2015; Sadutto et al., 2021). What reinforces the hypothesis of the impact of mineralogy is the frequent detection of very hydrophilic TrOCs in sediments (e.g. ACM, ATE), despite their high water solubility and theoretical low susceptibility to sorption (López-García et al., 2021; Thiebault et al., 2021b).

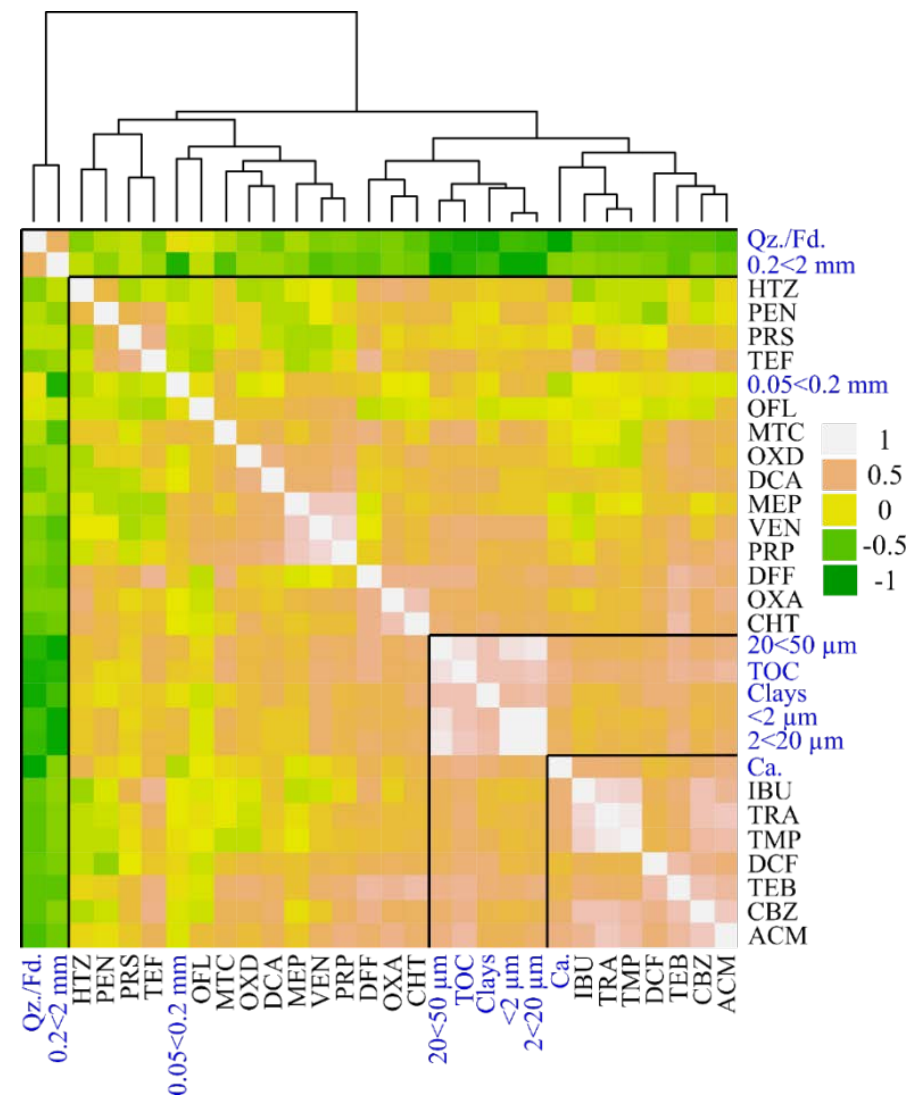

Figure 6: Heatmap analysis of the correlation coefficients between TrOC sedimentary concentrations and geochemical sediment analyses (full data Table S8)

According to the results of the statistical analysis, two parameters were anti-correlated with the others in a first cluster (Figure 6), namely inherited minerals (i.e. quartz and feldspaths) and coarse granulometry. This is unsurprising, as these two parameters are significantly correlated (Table S8) and are not favourable for the sorption of TrOCs due to their limited specific surface 
and reactivity. The other organo-mineral parameters of sediment (fine grainsize, clays and TOC) are all strongly intercorrelated. It is unfortunately impossible to clearly distinguish the respective impact of each of them, as 15 out of the 21 TrOCs are significantly correlated with both TOC and fine grainsize (Table S8). An attempt at correlation assessment using the sediment/water partition coefficient did not provide more precise results (Figure S2), and resulted in an almost identical clusterization.

Yet, what is worthy of note is the lack of TrOCs sorted by physico-chemical properties, reinforcing the assumption that in this context with significant spatial variations in TrOC aqueous concentrations, the source effect strongly impacts the solid/water partition of TrOC as well. Further work is required to clearly distinguish the impact of each organo-mineral parameter on TrOC occurrence, especially in highly urbanized areas carrying very diverse materials (Rivett et al., 2019).

\section{Conclusion}

The sediments of the Orge river catchment displayed a varied organo-mineral composition, with a low organic carbon content (i.e. between 0.5 and 8\%) and clay mineral content (i.e. between 0 and 9\%). This is consistent with conventional knowledge of river sediments, as is the fact that SPM were more organic and fine than sediments. This impacted the diversity and the concentration level of TrOCs within these two matrices as SPM displayed more diverse and concentrated contamination with higher detection frequencies than sediments among the 35 TrOCs investigated.

While it was not possible from a statistical point of view to clearly discriminate the respective impact of mineralogical composition, grainsize and TOC on the TrOC occurrences, it was clear that fine grainsize, high clay and TOC content are significantly correlated and can be considered as favourable for TrOC sorption. The impact of a flood particularly, generating the 
resuspension of fine particles from sediments, strongly contributes to validating this assumption.

From a spatial point of view, whereas the TrOC pattern in water samples was clearly impacted by WWTP effluent discharge, this was less clear concerning the two solid matrices. Environmental solids (i.e. SPM and sediments) have the potential to point out TrOC diversity along a watercourse to a certain extent, but the question of representativeness and standardisation of TrOC content still requires research.

\section{Acknowledgements}

This work was supported by the SITCOM project funded by Sorbonne University under the

“Tremplin nouveaux entrants et nouvelles entrantes de la FSI” programme. This work benefited from French state aid managed by the ANR under the "Investissements d'avenir" programme with the reference ANR-11-IDEX-0004-17-EURE-0006. E. Aubry, A. Guittet and S. Traoré are acknowledged for their technical assistance.

\section{References}

Al-Khazrajy, O.S.A., Boxall, A.B.A., 2016. Impacts of compound properties and sediment characteristics on the sorption behaviour of pharmaceuticals in aquatic systems. Journal of Hazardous Materials 317, 198-209. https://doi.org/10.1016/j.jhazmat.2016.05.065

Bexfield, L.M., Toccalino, P.L., Belitz, K., Foreman, W.T., Furlong, E.T., 2019. Hormones and Pharmaceuticals in Groundwater Used As a Source of Drinking Water Across the United States. Environmental Science \& Technology 53, 2950-2960. https://doi.org/10.1021/acs.est.8b05592

Birch, G.F., Drage, D.S., Thompson, K., Eaglesham, G., Mueller, J.F., 2015. Emerging contaminants (pharmaceuticals, personal care products, a food additive and pesticides) in waters of Sydney estuary, Australia. Marine Pollution Bulletin 97, 56-66. https://doi.org/10.1016/j.marpolbul.2015.06.038

Blanchoud, H., Farrugia, F., Mouchel, J.M., 2004. Pesticide uses and transfers in urbanised catchments. Chemosphere 55, 905-913. https://doi.org/10.1016/j.chemosphere.2003.11.061

Botta, F., Lavison, G., Couturier, G., Alliot, F., Moreau-Guigon, E., Fauchon, N., Guery, B., Chevreuil, M., Blanchoud, H., 2009. Transfer of glyphosate and its degradate AMPA to surface waters through urban sewerage systems. Chemosphere 77, 133-139. https://doi.org/10.1016/j.chemosphere.2009.05.008

Boulard, L., Dierkes, G., Schlüsener, M.P., Wick, A., Koschorreck, J., Ternes, T.A., 2019. Spatial distribution and temporal trends of pharmaceuticals sorbed to suspended particulate matter of German rivers. Water Research 115366. https://doi.org/10.1016/j.watres.2019.115366

Brodin, T., Fick, J., Jonsson, M., Klaminder, J., 2013. Dilute concentrations of a psychiatric drug alter behavior of fish from natural populations. Science 339, 814-815.

https://doi.org/10.1126/science.1226850 
Bruce, G.M., Pleus, R.C., Snyder, S.A., 2010. Toxicological relevance of pharmaceuticals in drinking water. Environmental Science \& Technology 44, 5619-5626. https://doi.org/10.1021/es1004895

Carter, A., 2000. How pesticides get into water - and proposed reduction measures. Pesticide Outlook $11,149-156$.

Castro, O.G., Vale, C., 1995. Total PCB-organic matter correlation in sediments from three estuarine areas of Portugal. Netherland Journal of Aquatic Ecology 29, 297-302. https://doi.org/10.1007/BF02084228

Chemspider Database, n.d. http:\/chemspider.com. URL http://www.chemspider.com/ (accessed 9.16.21).

Daughton, C.G., 2004. Non-regulated water contaminants: emerging research. Environmental Impact Assessment Review, Environment and Health: new answers, new questions. 24, 711-732. https://doi.org/10.1016/j.eiar.2004.06.003

Dendievel, A.-M., Grosbois, C., Ayrault, S., Evrard, O., Coynel, A., Debret, M., Gardes, T., Euzen, C., Schmitt, L., Chabaux, F., Winiarski, T., Van Der Perk, M., Mourier, B., 2022. Key factors influencing metal concentrations in sediments along Western European Rivers: A long-term monitoring study (1945-2020). Science of The Total Environment 805, 149778. https://doi.org/10.1016/j.scitotenv.2021.149778

Dinh, Q.T., Moreau-Guigon, E., Labadie, P., Alliot, F., Teil, M.-J., Blanchard, M., Chevreuil, M., 2017a. Occurrence of antibiotics in rural catchments. Chemosphere 168, 483-490. https://doi.org/10.1016/j.chemosphere.2016.10.106

Dinh, Q.T., Moreau-Guigon, E., Labadie, P., Alliot, F., Teil, M.-J., Blanchard, M., Eurin, J., Chevreuil, M., 2017b. Fate of antibiotics from hospital and domestic sources in a sewage network. Science of The Total Environment 575, 758-766. https://doi.org/10.1016/j.scitotenv.2016.09.118

Dordio, A.V., Miranda, S., Ramalho, J.P.P., Carvalho, A.J.P., 2017. Mechanisms of removal of three widespread pharmaceuticals by two clay materials. Journal of Hazardous Materials 323, 575583. https://doi.org/10.1016/j.jhazmat.2016.05.091

Droge, S.T.J., Goss, K.-U., 2013a. Development and Evaluation of a New Sorption Model for Organic Cations in Soil: Contributions from Organic Matter and Clay Minerals. Environmental Science \& Technology 47, 14233-14241. https://doi.org/10.1021/es4031886

Droge, S.T.J., Goss, K.-U., 2013b. Ion-Exchange Affinity of Organic Cations to Natural Organic Matter: Influence of Amine Type and Nonionic Interactions at Two Different pHs. Environmental Science \& Technology 47, 798-806. https://doi.org/10.1021/es3033499

Farré, M. la, Pérez, S., Kantiani, L., Barceló, D., 2008. Fate and toxicity of emerging pollutants, their metabolites and transformation products in the aquatic environment. TrAC Trends in Analytical Chemistry 27, 991-1007. https://doi.org/10.1016/j.trac.2008.09.010

Gogoi, A., Mazumder, P., Tyagi, V.K., Tushara Chaminda, G.G., An, A.K., Kumar, M., 2018. Occurrence and fate of emerging contaminants in water environment: A review. Groundwater for Sustainable Development 6, 169-180. https://doi.org/10.1016/j.gsd.2017.12.009

Golovko, O., Rehrl, A.-L., Köhler, S., Ahrens, L., 2020. Organic micropollutants in water and sediment from Lake Mälaren, Sweden. Chemosphere 258, 127293. https://doi.org/10.1016/j.chemosphere.2020.127293

Gwenzi, W., Chaukura, N., 2018. Organic contaminants in African aquatic systems: Current knowledge, health risks, and future research directions. Science of The Total Environment 619-620, 1493-1514. https://doi.org/10.1016/j.scitotenv.2017.11.121

Hörsing, M., Ledin, A., Grabic, R., Fick, J., Tysklind, M., Jansen, J. la C., Andersen, H.R., 2011. Determination of sorption of seventy-five pharmaceuticals in sewage sludge. Water Research 45, 4470-4482. https://doi.org/10.1016/j.watres.2011.05.033

Kay, P., Hughes, S.R., Ault, J.R., Ashcroft, A.E., Brown, L.E., 2017. Widespread, routine occurrence of pharmaceuticals in sewage effluent, combined sewer overflows and receiving waters. Environmental Pollution 220, 1447-1455. https://doi.org/10.1016/j.envpol.2016.10.087

Kerrigan, J.F., Sandberg, K.D., Engstrom, D.R., LaPara, T.M., Arnold, W.A., 2018. Sedimentary record of antibiotic accumulation in Minnesota Lakes. Science of The Total Environment 621, 970-979. https://doi.org/10.1016/j.scitotenv.2017.10.130 
Kodešová, R., Grabic, R., Kočárek, M., Klement, A., Golovko, O., Fér, M., Nikodem, A., Jakšík, O., 2015. Pharmaceuticals' sorptions relative to properties of thirteen different soils. Science of The Total Environment 511, 435-443. https://doi.org/10.1016/j.scitotenv.2014.12.088

Ledieu, L., Simonneau, A., Thiebault, T., Fougere, L., Destandau, E., Cerdan, O., Laggoun, F., 2021. Spatial distribution of pharmaceuticals within the particulate phases of a peri-urban stream. Chemosphere 279, 130385. https://doi.org/10.1016/j.chemosphere.2021.130385

Lepage, H., Launay, M., Le Coz, J., Angot, H., Miège, C., Gairoard, S., Radakovitch, O., Coquery, M., 2020. Impact of dam flushing operations on sediment dynamics and quality in the upper Rhône River, France. Journal of Environmental Management 255, 109886. https://doi.org/10.1016/j.jenvman.2019.109886

Li, J., Carter, L.J., Boxall, A.B.A., 2020. Evaluation and development of models for estimating the sorption behaviour of pharmaceuticals in soils. Journal of Hazardous Materials 392, 122469. https://doi.org/10.1016/j.jhazmat.2020.122469

Li, S.-W., Lin, A.Y.-C., 2015. Increased acute toxicity to fish caused by pharmaceuticals in hospital effluents in a pharmaceutical mixture and after solar irradiation. Chemosphere 139, 190-196. https://doi.org/10.1016/j.chemosphere.2015.06.010

Loos, R., Carvalho, R., António, D.C., Comero, S., Locoro, G., Tavazzi, S., Paracchini, B., Ghiani, M., Lettieri, T., Blaha, L., Jarosova, B., Voorspoels, S., Servaes, K., Haglund, P., Fick, J., Lindberg, R.H., Schwesig, D., Gawlik, B.M., 2013. EU-wide monitoring survey on emerging polar organic contaminants in wastewater treatment plant effluents. Water Research 47, 64756487. https://doi.org/10.1016/j.watres.2013.08.024

López-García, E., Mastroianni, N., Ponsà-Borau, N., Barceló, D., Postigo, C., López de Alda, M., 2021. Drugs of abuse and their metabolites in river sediments: Analysis, occurrence in four Spanish river basins and environmental risk assessment. Journal of Hazardous Materials 401, 123312. https://doi.org/10.1016/j.jhazmat.2020.123312

Mader, B.T., Uwe-Goss, K., Eisenreich, S.J., 1997. Sorption of nonionic, hydrophobic organic chemicals to mineral surfaces. Environmental Science \& Technology 31, 1079-1086. https://doi.org/10.1021/es960606g

Niu, L., Ahlheim, J., Glaser, C., Gunold, R., Henneberger, L., König, M., Krauss, M., Schwientek, M., Zarfl, C., Escher, B.I., 2021. Suspended Particulate Matter-A Source or Sink for Chemical Mixtures of Organic Micropollutants in a Small River under Baseflow Conditions? Environmental Science \& Technology 55, 5106-5116. https://doi.org/10.1021/acs.est.0c07772

Nunes, B., Carvalho, F., Guilhermino, L., 2005. Acute toxicity of widely used pharmaceuticals in aquatic species: Gambusia holbrooki, Artemia parthenogenetica and Tetraselmis chuii. Ecotoxicology and Environmental Safety 61, 413-419. https://doi.org/10.1016/j.ecoenv.2004.08.010

Nunes, C.N., dos Anjos, V.E., Quináia, S.P., 2019. Are there pharmaceutical compounds in sediments or in water? Determination of the distribution coefficient of benzodiazepine drugs in aquatic environment. Environmental Pollution 251, 522-529. https://doi.org/10.1016/j.envpol.2019.05.015

Paijens, C., Bressy, A., Frère, B., Tedoldi, D., Mailler, R., Rocher, V., Neveu, P., Moilleron, R., 2021. Urban pathways of biocides towards surface waters during dry and wet weathers: Assessment at the Paris conurbation scale. Journal of Hazardous Materials 402, 123765. https://doi.org/10.1016/j.jhazmat.2020.123765

Poulier, G., Launay, M., Le Bescond, C., Thollet, F., Coquery, M., Le Coz, J., 2019. Combining flux monitoring and data reconstruction to establish annual budgets of suspended particulate matter, mercury and PCB in the Rhône River from Lake Geneva to the Mediterranean Sea. Science of The Total Environment 658, 457-473. https://doi.org/10.1016/j.scitotenv.2018.12.075

Quesada, S., Tena, A., Guillén, D., Ginebreda, A., Vericat, D., Martínez, E., Navarro-Ortega, A., Batalla, R.J., Barceló, D., 2014. Dynamics of suspended sediment borne persistent organic pollutants in a large regulated Mediterranean river (Ebro, NE Spain). Science of The Total Environment 473-474, 381-390. https://doi.org/10.1016/j.scitotenv.2013.11.040

Rivett, M.O., Roche, R.S., Tellam, J.H., Herbert, A.W., 2019. Increased organic contaminant residence times in the urban riverbed due to the presence of highly sorbing sediments of the 
Anthropocene. Journal of Hydrology X 3, 100023.

https://doi.org/10.1016/j.hydroa.2019.100023

Sadutto, D., Andreu, V., Ilo, T., Akkanen, J., Picó, Y., 2021. Pharmaceuticals and personal care products in a Mediterranean coastal wetland: Impact of anthropogenic and spatial factors and environmental risk assessment. Environmental Pollution 271, 116353. https://doi.org/10.1016/j.envpol.2020.116353

Schaffer, M., Boxberger, N., Börnick, H., Licha, T., Worch, E., 2012. Sorption influenced transport of ionizable pharmaceuticals onto a natural sandy aquifer sediment at different $\mathrm{pH}$. Chemosphere 87, 513-520. https://doi.org/10.1016/j.chemosphere.2011.12.053

Scheytt, T., Mersmann, P., Lindstädt, R., Heberer, T., 2005. Determination of sorption coefficients of pharmaceutically active substances carbamazepine, diclofenac, and ibuprofen, in sandy sediments. Chemosphere 60, 245-253. https://doi.org/10.1016/j.chemosphere.2004.12.042

Stachel, B., Jantzen, E., Knoth, W., Krüger, F., Lepom, P., Oetken, M., Reincke, H., Sawal, G., Schwartz, R., Uhlig, S., 2005. The Elbe Flood in August 2002-Organic Contaminants in Sediment Samples Taken After the Flood Event. Journal of Environmental Science and Health, Part A 40, 265-287. https://doi.org/10.1081/ESE-200045531

Stein, K., Ramil, M., Fink, G., Sander, M., Ternes, T.A., 2008. Analysis and sorption of psychoactive drugs onto sediment. Environmental Science \& Technology 42, 6415-6423. https://doi.org/10.1021/es702959a

Svahn, O., Björklund, E., 2015. Describing sorption of pharmaceuticals to lake and river sediments, and sewage sludge from UNESCO Biosphere Reserve Kristianstads Vattenrike by chromatographic asymmetry factors and recovery measurements. Journal of Chromatography A 1415, 73-82. https://doi.org/10.1016/j.chroma.2015.08.061

Thiebault, T., 2020. Raw and modified clays and clay minerals for the removal of pharmaceutical products from aqueous solutions: state of the art and future perspectives. Critical Reviews in Environmental Science and Technology 50, 1451-1514. https://doi.org/10.1080/10643389.2019.1663065

Thiebault, T., Alliot, F., Berthe, T., Blanchoud, H., Petit, F., Guigon, E., 2021a. Record of trace organic contaminants in a river sediment core: From historical wastewater management to historical use. Science of The Total Environment 773, 145694. https://doi.org/10.1016/j.scitotenv.2021.145694

Thiebault, T., Fougère, L., Simonneau, A., Destandau, E., Le Milbeau, C., Jacob, J., 2021b. Occurrence of drug target residues within decantation tank sediments: a good clue to assess their historical excretion? Sustainable Environment Research 31, 18. https://doi.org/10.1186/s42834-021-00092-w

Tran, N.H., Reinhard, M., Gin, K.Y.-H., 2018. Occurrence and fate of emerging contaminants in municipal wastewater treatment plants from different geographical regions-a review. Water Research 133, 182-207. https://doi.org/10.1016/j.watres.2017.12.029

Vazquez-Roig, P., Andreu, V., Blasco, C., Picó, Y., 2012. Risk assessment on the presence of pharmaceuticals in sediments, soils and waters of the Pego-Oliva Marshlands (Valencia, eastern Spain). Science of The Total Environment 440, 24-32. https://doi.org/10.1016/j.scitotenv.2012.08.036

Verlicchi, P., Zambello, E., 2015. Pharmaceuticals and personal care products in untreated and treated sewage sludge: Occurrence and environmental risk in the case of application on soil - A critical review. Science of The Total Environment 538, 750-767. https://doi.org/10.1016/j.scitotenv.2015.08.108

Warner, W., Licha, T., Nödler, K., 2019. Qualitative and quantitative use of micropollutants as source and process indicators. A review. Science of The Total Environment 686, 75-89. https://doi.org/10.1016/j.scitotenv.2019.05.385

Yamamoto, H., Nakamura, Yudai, Moriguchi, S., Nakamura, Yuki, Honda, Y., Tamura, I., Hirata, Y., Hayashi, A., Sekizawa, J., 2009. Persistence and partitioning of eight selected pharmaceuticals in the aquatic environment: Laboratory photolysis, biodegradation, and sorption experiments.

Water Research 43, 351-362. https://doi.org/10.1016/j.watres.2008.10.039

Zhou, J., Broodbank, N., 2014. Sediment-water interactions of pharmaceutical residues in the river environment. Water Research 48, 61-70. https://doi.org/10.1016/j.watres.2013.09.026 
